\title{
Influence of problem-based learning strategy on enhancing student's industrial oriented competences learned: an action research on learning weblog analysis
}

\author{
Pansy Chung ${ }^{1}$ (D) Ron Chuen $\mathrm{Yeh}^{2} \cdot$ Yi-Cheng Chen ${ }^{3}$
}

Accepted: 23 March 2015/Published online: 18 April 2015

(C) The Author(s) 2015. This article is published with open access at Springerlink.com

\begin{abstract}
In order to respond to the ever-changing global economic environment, the technological and vocational education system in Taiwan needs to be dramatically reformed to the changing needs of the domestic industrial structure. Integrating practical talents with practical industrial experiences and competences can help avoid discrepancy and close the gap between vocational education and the practical demands of industries. Thus, to achieve the goals of technological and vocational education, it is necessary to incorporate instruction that meets the demands of the industrial-oriented manpower in Taiwan. In this study, the well-known problem-based learning (PBL) approach, utilized commonly in the educational area of medicine and business management, was integrated with the qualitative method of action research to explore how such a learning strategy could influence college students' learning outcomes regarding industrial-oriented competences. The research results were induced from the empirical data collected via participatory classroom observations, and analyses of teachers' instructional journals and semi-structural interviews. A survey with quasi-experimental design of the control group pretest and posttest was conducted by using an industrial-oriented competences scale to explore the influences of PBL on students' learning outcomes of industrial-oriented competences. The findings are expected to shed light on the teaching and learning strategy
\end{abstract}

Pansy Chung

pcmeiho@gmail.com; x00003046@meiho.edu.tw

Ron Chuen Yeh

rcyeh@meiho.edu.tw

Yi-Cheng Chen

yc_bear@nttu.edu.tw

1 Present Address: Department of Information Management, Meiho University, 23 Pingkuang Rd., Neipu, Pingtung 91202, Taiwan

2 Department of Business Administration, Meiho University, 23 Pingkuang Rd., Pingtung 91202, Taiwan

3 Department of Information Science and Management Systems, National Taitung University, Taitung, Taiwan 
of college students' industrial-oriented competences and contribute to theoretical implications and future educational and industrial development of Taiwan.

Keywords Problem-based learning (PBL) - Industrial-oriented competences ·

Action research $\cdot$ Weblog $\cdot$ Competence

\section{Introduction}

After the international financial crisis of 2007-2008, countries and institutions had to respond to the unstable global economic environment. The technological and vocational education system in Taiwan must adjust and reorganize appropriately, to meet the demands of the domestic industrial structure. In the 2013 white paper of Taiwan's education policy, Taiwan's Ministry of Education clearly stated the critical strategies including "improving the quality and professionalism of polytechnic education, developing exemplary polytechnical colleges and improving polytechnic education, building college characteristics, encouraging universities/colleges to hire industry experts as instructors, reinforcing industry-academia links, improving the ability of polytechnical college students to become employed.", and "facilitating the linkage between training for higher education professionals and industry needs." In this regard, curricula of the Taiwanese technological and vocational higher-education environment needs to further meet the "practical learning and application" teaching goals. To meet the demands for technological and vocational talents in this new era, educational institutions must treat new curriculum planning and reformed instructional development as priorities; especially the primary learning objectives for the majority of students in Taiwan who attend vocational schools are industrial and/or practical knowledge and skills acquisition. Hence, technological and vocational educational institutions should enhance their core competency learning and skill acquisition.

In regard to educational requirements, the industrial corporations seek students with employable technical talents, specifically those with practical industrial work experience and competences. Using the manufacturing industry as an example, hiring companies expect students to be highly educated in modern technology in order to cultivate successful Engineering and Industrial technologists. Generally speaking, it is necessary to further review and to explore the effects of technological and vocational education, specifically in the context of post-graduate career opportunities alongside the demands of the labor and industrial-oriented sects (Hung 2008). Roberts (1957) indicated a technical high school, the first was established in 1898, or the technical group in a comprehensive high school offered a choice of curricula and recognized the growing demand for courses leading more definitely towards a vocation. A Federal Committee on apprentice training was created by the US President in 1934 and the Committee recommended certain standards to be used as guides by employers and employees for establishing standards in a specified trade. These provided the concept of school education should meet the industry need. Mager (1962) provided background details on competences and competency based education, and influenced school systems for decades and continues to shape the vast majority of corporate training programs developed today. These historical developments helped to establish industrial competence standards as suggested by a psychologist from Harvard University (McClelland 1973). It is important to note however that the term varies among different 
cultures. Within the Chinese and Taiwanese context, "competence" refers to the external behavioral-performance upon which knowledge, skill and attitude is measured. According to other scholars, competence relates to a person's effective performance of values, attitudes inferences and judgment (Lysaght and Altschuld 2000). Competence can be divided into "Generic competence," "Professional competence," (Weinert 1999) and, "Managerial competence" in the workplace (Boddy et al. 1995; MCI 1990; Thorpe and Holman 1994). When discussing the development of technological learning in this paper, one should refer to the cultivation of key competences and problem solving. It is in that sense that the "practical monograph" courses in Taiwanese higher technology education are thus planned to meet actual demands of the industrial environment. Students are exposed to the course of practical monograph through various theories and on-site visits. They are then equipped to meet the demands of employment in the industrial corporations upon graduation (Chen 2010). To measure the competency of graduating students, this study used the Delphi technique, Yeh et al. (2010). It is a technique developed so as to use the "industrial-oriented competences scale" which allows business and management students to self-evaluate their qualifications in an industrially-oriented environment. By using this technique, students are able to recognize the core competences of university students in the management field, which are required by the companies in the current industrial environment.

In university education, teachers are able to better understand students' competences through results from "industrial-oriented competences scale" surveys. Through which, teachers can properly develop the curriculum that meets student needs. Unlike elementary schools and high schools in Taiwan (which are regulated by the Ministry of Education of the central government and the Education Bureau of the local governments), universities in Taiwan are regulated by the Taiwan University Act, under which course planning and teaching activities are solely overseen by the teachers. Therefore, no matter how well the instructional methods and learning approaches are designed, or how successfully they have been implemented in high school and elementary school education, they still may not be adopted in universities, or in management education. This study applied the widely used and approved Problem-based learning (PBL) technique. This methodology can be found in medical education (Boud and Feletti 1998; Wilkerson and Gijselaers 1996) specifically in practical monograph courses and in business management education in technological institutions. Although PBL is not widely applied to management education, Hallinger and Bridges (2010) demonstrated the feasibility of PBL application in management education. Thus, with the combination of the qualitative study as the main approach and the quantitative study as the secondary approach, this study probes into students' industrial-oriented competences and learning outcomes after experiencing PBL, and additionally evaluated the teachers' reflections after the implementation of PBL. Based on motives mentioned above, the research objectives are:

1. to understand the actual thoughts and gratification of business and management students after receiving PBL.

2. to understand the actual thoughts and gratification of business and management teachers after including PBL in practical monograph course teaching.

3. to understand business and management students' changes in industrial-oriented competences after receiving PBL and their learning outcomes before and after PBL. 


\section{Literature review}

\section{Practical monograph}

Higher technological and vocational education in Taiwan emphasizes "practical" study and "industrial and academic collaboration" with industries. However, because of inadequate preparation in school study before going for industry internship, students' internship in industries usually cannot be arranged properly and may not necessarily be related to the knowledge learned in their major or in specific classes. Therefore, there are courses related to "practical monograph" (or Project Design) in technological and vocational institutes in Taiwan, which serve to supplement the aspects mentioned above, and which integrate teachers' lectures in class with students' project study in industries. "Practical monograph" is distinct from traditional classroom lectures, with the aim of allowing students to apply professional knowledge and learned theory, while also having the capability to develop primary exploration and future research potentials. In other words, practical monograph emphasizes the practicality of vocational education and expects to meet the standards of industrial development. The research themes are preferably related to the issues that industries intend to explore. Therefore, "Practical monograph" courses are integrated project studies which satisfy the actual needs of industries. The approach of this course is to allow students to choose the direction of their studies according to their interests, based upon existing basic professional theories. They self-select the advisers, set the topics and conduct the study under the advisers' guidance and supervision. Other than defining research questions, data collection, data analysis, finding the possible solutions, assessing alternatives, trial and result evaluation, PBL courses also aim to cultivate students' problem-solving skills to achieve these goals on four levels: (1) enhance students' comprehension; (2) enhance students' expression competence; (3) enable students to recognize the gap between practice and theory, by: conducting practice and experiment in class, visiting industries, and carrying out interns at industries; (4) and by equipping students with problem-solving competence.

In essence, "practical monograph" courses are meant to integrate theories with practice, allowing students to interact with industries. Furthermore, they are designed to help the students better understand the business process of industry to save staff training costs in the future. In the meantime, it provides a way for students to decide if they are interested in the industry. The objective of the practical monograph course is to integrate theory, on-site visit, questionnaire survey, statistical analysis and report writing activities together to develop students' independent thinking, practical experience and competence. "Practical monograph" expects students to work in groups to finish formal papers or project reports by observing facts, collecting related information, systematically analyzing data, and discovering problems and solutions before graduation. It aims to (1) enhance students' competence of data collection and reading of related literature, (2) enhance individual competence in systematic thinking, (3) increase report writing and oral report competence, (4) develop team oriented problem-solving competence, (5) cultivate research skills for advanced study, (6) enhance student's competence to blend into industry requirements and practice (Chen 2010).

\section{Industrial-oriented competences}

McClelland (1973) indicated that the concept of "competence" varies among different cultures. In this context, competence is the external behavioral performance based upon 
one's knowledge, skill and attitude. It is also a person's effective performance of values, attitude, inference and judgment (Lysaght and Altschuld 2000). "Management competence provides a potentially useful lens through which to frame these and other questions" (Sadler-Smith et al. 2003), in which "knowledge, affection and skill are needed for fulfilling the task or certain jobs". Competence can be divided into generic competence and professional competence (Weinert 1999). Management charter initiative (MCI) of Britain is most commonly used to define the managerial competence needed by managers in the workplace (Boddy et al. 1995; MCI 1990; Thorpe and Holman 1994). Therefore, technological and vocational learning must develop both the cultivation of key competences and problem-solving competence. The European Training Foundation (ETF) suggests that the competence criterion is the interface between technological and vocational education, and the job market. In other words, in order to cultivate student's competent talents for industries, educational institutions of technology must provide proper courses which reflect the demand of the job market. For the purpose of reducing the competence gap and enhancing the research, competence criterion will be one of the best measures.

In today's global economic challenge, Taiwan is not the only country encountering the issue of gainful employment all of the graduating university students. Many developed countries in the world also face the same situation. In 1999, the "Bologna Declaration" signed by the ministers of education of 29 European countries treated the "enhancement of student's employability" as one of the objectives of university reform. Gordon (1991) was the first scholar to propose "industrial domination". However, in order to respond to international economic situations and changes of domestic industrial structure, the government, industry, academia and the R\&D industry of Taiwan have focused on "industrialoriented competence" development since 2008. The National Science Council (2008) defined "industrial-oriented competence" as the development of curriculum and instruction design which meets the student's background and the demands of industry. Jou (2009) suggested that industrial-oriented competences enhanced student's practical competence and job opportunities through diverse and multiple ways of learning. It allowed the students to be competent in their workplace right after their graduation. In the changing environment of diversified industry, the industries' requirement for employees' competence has also changed significantly. It turned from "professional competence" emphasizing cognition and technique to a more balanced combination between "professional competence" and "key competence" (Burchell et al. 1999, 2000; Calway and Murphy 2000). In order to explore the required industrial-oriented competences for business and management students, Yeh et al. (2010) defined industrial-oriented core competences by using the Delphi technique. The three competence categories; generic competence, professional competence, and workforce competence were identified to include a total of 16 core competences. These core competences can help universities prepare the appropriate curriculum and guide business majors to learn the skills required by the industry.

\section{Problem-based learning}

Problem-based learning (PBL) is perhaps one of the most innovative pedagogical methods ever implemented in education. Its effectiveness in facilitating student problem-solving and self-directed learning skills has become increasingly popular across disciplines in higher education (Hung et al. 2008). PBL was first conceived in the early 1960s at a medical college. It was developed as a learning method to implement constructivism. It is a learner-centered form of education, based on non-structural issues in reality and the process of the learners' active problem solving. In the process of learning, learners play the 
roles of active problem solvers, and are responsible for learning and cultivating selforiented lifelong learning skills, problem-solving competence, and communication skills for team work. Teachers on the other hand, play secondary roles, where they become partners in learners' problem solving. They are the guides, consultants and coaches. PBL aims to encourage students to ponder on "what to learn and how to learn" by issuing ambiguous structures and definitions in real situations, and they are there to change, modify and expand the process by collaborative learning. Finkle and Trop (1995) suggested that problem-oriented instructions address both curriculum development and instructional systems, which also develop problem-solving strategy, knowledge database and skill learning. Learners that were involved in meaningful or real learning situations were thus able to adapt to problems in real life. Learners were provided with useful resources, instruction and exploration; thus, they were active in problem-solving in order to construct knowledge and problem-solving skills.

Although traditional lecture instruction allows students to obtain knowledge, students will not be able to solve problems in the real world with merely classroom knowledge acquisition (West and Watson 1996). Barrett (2005), Sage (2000) and Stepien (2002) all suggested that PBL should integrate technology in various measures, such as e-mail, briefing message, internet tools and special software. In problem solving, where technology can provide more favorable and effective tool selection, as well as confirm and organize information, learners can be creative in multiple dimensions and cooperate with each other to solve the problems. However, business technique courses aim to cultivate students' skills, combine instructional content with students' life experience, trigger students' learning motivation and values teaching method to cultivate students' team work. PBL is an instructional activity that can motivate students toward an educational approach of "learning to learn". Thus, students in groups can find ways to develop real-life problemsolving capabilities and develop the competences to become self-guided learners. PBL therefore refers to competence learning pedagogy instead of simply to traditional knowledge acquisition techniques (Wu 2002). This ultimately allows students to step outside their expectations about how to learn (Keegan and Turner 2001).

Based on studies of several scholars, a PBL model includes five stages: analysis, design, development, implementation and evaluation. The whole process is based on team work and discussion. Students actively analyze the problems and ponder on their recognition of the issues. They obtain and compare new knowledge, reorganize what they have learned and experience, and are in charge of finding the necessary means for problem solving. In comparison to traditional instructions dominated by teachers, PBL is more inspiring (Aleman and Lopez 2000; Delisle 1997; Haith-Cooper 2000; Hong 2001; Jih and Chang 2001; Schank 1994; Song et al. 2006). From the perspective of learners, students in a PBL team must solve the problems by more open, reflective, critical and active learning attitudes, in comparison with traditional courses (Margetson 1991; Engel 1997). For teachers, PBL allows students to mutually challenge the problems, search for problem-solving plans, explore new knowledge in experience, obtain more practical experience and become better learners with self-learning capability (Hewitt-Taylor 2002; Connolly and Donovan 2002).

The world is in a time of rapid development in the economy of knowledge, with a wide array of technological information in a fast changing society. In order to meet the coming of a knowledge based society and face its new challenges, suitable professional talents are required. After graduation, most students from traditional instruction but learning systems have difficulty adapting to the workplace and do not meet the demands of industry. A good learning method must suit different instructional strategies and be demonstrated to be effective after evaluation (Felder and Brent 2005). Therefore, in recent years, different 
learning approaches have been introduced and curriculum content is being revised in Taiwan and other foreign countries. PBL originated from within medical education but since it trains students' competence to deal with problems in reality, it is gradually becoming popular in the educational fields of law, business, administration management, engineering college, chemistry, physics, educational psychology and educational administration in higher education. Some scholars (Boud and Feletti 1998; Wilkerson and Gijselaers 1996) have observed that PBL is being widely applied in medical education, but is still rare in management education. Tseng et al. (2008) also indicated the PBL was not used widely in research methods and instructional practice by engineering education in the past. Therefore, Hallinger and Bridges (2010) applied PBL to management education and students' learning outcomes were observed to be better than those with ordinary learning approaches.

\section{Research methodology}

This action-study investigates the influence of applying PBL strategy in practical monograph teaching, to the competences learned by students in business majors. Fifty-one junior students in a practical monograph course of the Business Administration Department of Meiho University in Taiwan were chosen, and non-homogeneously divided into 14 groups. Each group consisted of 3 to 4 students with three units of instructional activities that were carried out in each group over 11 weeks. By collecting students' learning data through participation and observation in the classroom, reviewing the instructor's teaching journals, and by semi-structural interviews, students' changes in learning of industrial-oriented competences were analyzed. In addition, the quantitative study by "questionnaire survey" was treated as the secondary approach. A quasi-experimental designed signal group pretest and posttest was constructed and implemented by using the questionnaires developed by Yeh et al. (2010). The data were analyzed by using descriptive statistics, independent sample $t$ test and dependent sample $t$ test.

\section{Action research}

Action research originated in the U.S.A. in the 1930s. The term was coined by John Collier in 1945. In the 1960s, the educational reform of Britain and Australia influenced it to become the model for curriculum development and teachers' advanced study. Lewin (1946) suggested that social issues at the time were what drove classroom social studies and thus appropriately developed the social exploration model with a plan, an action, an observation and a reflection. These studies propelled John Collier and Kurt Lewin to become the main pioneers of action research that particularly emphasized empirical cognition that treated locality, practicability and problem solving as purposes. These research studies combined scholars with actual workers to construct a collaborative research team (Reason and Bradbury 2001). In essence, the action research method exists in social situations where it aims to improve real-world problems in society (Elliott 1991). Many scholars are gradually adopting this approach to research.

The concept of action research is also popular in the educational field. Two important promoters of action research in British education, Lawrence Stenhouse and John Elliott, have both further suggested post-learning action research (McNiff 1988). Lawrence Stenhouse first proposed the concept that "teachers are researchers" when he popularly 
promoted school-based curriculum reform. Elliot emphasized the importance of action to enhance reflection (Elliott 1991). By the action research of educational courses, teachers can identify and solve many problems in instruction and learning. In comparison to other research approaches, action research can develop profound knowledge and competence in classrooms and are thus more sensitive to educational practice (Ou 1999). John Elliot agreed that action and reflection are two activities in constant cycle. In considering inducing more flow into the cycle, he suggested cycles within a cycle. Pittaway and Cope (2007) also indicated that the teacher's actions also require reflection and adaptation to circumstances. "Educational action research," by Stephen Kemmis, encouraged teachers to be reflective researchers of their own instruction. Teachers should treat the self-reflection cycle of "plan, action, observation, reflection and re-plan" as the bases for a problem-solving strategy. The cycle is constantly sequential and develops different concepts and behaviors to fulfill the goal. Users can solve problems, acquire knowledge and learn to re-identify ones' self in action (Dick 2002).

By combining the characteristics of PBL and action research, the researcher plays the roles of instructor, learning assistant and researcher. Therefore, from the beginning, the researcher analyzes problems; designs' teaching plans and then develops and implements instructional activities. Besides lecturing, the researcher assists students in overcoming the obstacles to learning. Two teachers observe and record students' learning process and instructors teaching methods. They also summarize the observation process by interviewing students and teachers on how they perceived the teaching/learning went. They conduct course-learning evaluations and reflections, and use results to plan the next teaching program. The cycle continues until the end of the course, as shown in the following conceptual framework (Fig. 1).

\section{Instrument development}

Based upon the scale of a graduate's industrial-oriented competence (SGIOC) for the business department of technological and vocational institutions (Yeh et al. 2010), this study was developed to survey the three competence categories (generic competence, professional competence and workforce competence) and relate them to the 16 core competences (see Table 1). The three categories of competencies are defined as: (1) Generic competence: generic competencies originate from the characteristics of individuals and are acquired through cumulative past experiences. Generic competencies are

Fig. 1 Conceptual framework of PBL characteristics and action research

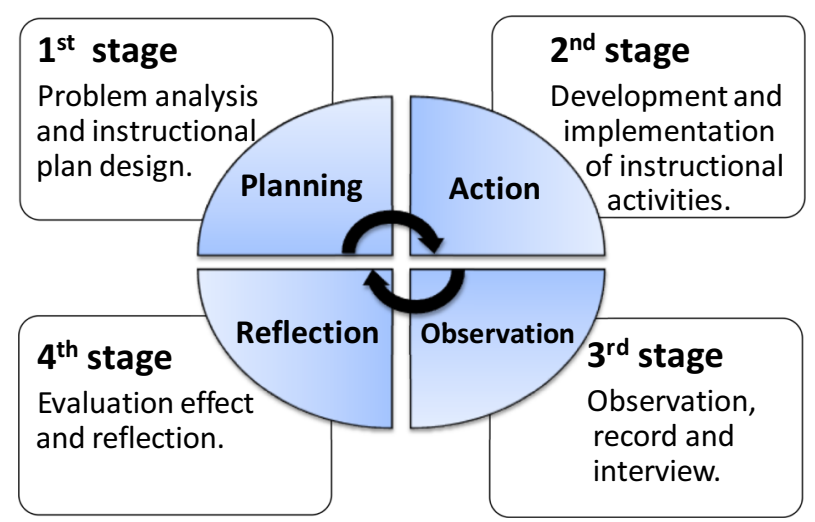


Table 1 Structure of the industrial-oriented competencies

\begin{tabular}{ll}
\hline Competence category & Core competence \\
\hline 1. Generic competence & 1.1 Using computers \\
& 1.2 Communication \\
2. Professional competence & 1.3 Language skills \\
& 1.4 Problem-analysis and problem-solving \\
& 2.2 . Marketing management \\
& 2.3. Customers relationship management \\
& 2.4 . Human resources management \\
2.5. Financial management \\
2.6. Accounting and statistical analysis \\
2.7. E-commerce applications \\
3.1. Team work \\
3.2. Self-learning \\
3.3. Self-discipline \\
3.4. Leadership \\
3.5. Work ethic
\end{tabular}

the most basic skills required to survive in a competitive environment; (2) Professional competence: professional knowledge, skills and attitudes required for a certain business or job. The professional competence requirements for business-major students are determined from the five areas, including production and operation management, marketing management, human resources management, research and development, and financial management; (3) Workforce competence: competencies that are equally applicable in any other business sectors, and they include favorable attitudes and personal characteristics generally pursued by potential employers.

Generic competence means the competence of ordinary people as they adapt to and are competent in different job demands. It mainly includes people's knowledge and skills that can be directly learned from courses in schools, for example: common subjects and general courses, including using computers, communication, language skills, problem-analysis and problem-solving. Professional competence refers to the professional technical competence required for specific industries. Professional competence of industrial-oriented business students includes production and operation management competence, marketing management competence, customer relationship management competence, human resource management competence, financial management competence, accounting and statistical analysis competence and E-commerce application competence. Workforce competence refers to the competence that can be applied to all sorts of different work environments, regardless of the kind of business. This usually includes having a positive attitude towards both work and learning, as well as having favorable personal characteristics, which are generally pursued by potential employers. Workforce competence usually cannot be learned directly from courses in a classroom but instead by imperceptible instruction (such as teachers' teaching methods, school culture, etc.). By observing knowledge, values, regulations or attitudes, students gradually internalize these components as part of their cognitions, which allows them to eventually develop their senses of team work, self- 
learning, self-discipline, leadership, as well as work ethic competencies. In the quantitative study, upon finishing the PBL teaching, the researcher conducted a questionnaire survey by using the SGIOC questionnaire to find if there were any significant differences between pretest and posttest results in industrial-oriented competences.

\section{Sampling and data collection}

According to the conceptual framework (see Fig. 2) and industrial-oriented competences, researchers divided "practical monograph" into three units (generic competence, professional competence and workforce competence). They also conducted qualitative and quantitative data collection, coding, analysis, and reliability and validity test.

\section{Data collection}

Before action research, PBL was applied to design of the teaching plans. Then, instructional activities were implemented according to the teaching plans. The researcher recorded every detail per the instructions, discovering problems by self-reflection and modifying action strategy in order to solve the problems. In the teaching of unit courses, this study recorded the students' situation in classrooms and through expert interviews. This indicates the students' learning performance in each "classroom observation record". Thus, when analyzing data, the researcher can obtain more relative information. This enhanced the action research and functioned as criterion for future research. As to the learning sheet, according to suggestions from the scholars (Barrett 2005; Sage 2000; Stepien 2002), PBL should integrate technology by various means, provide more favorable and effective tools for selection, as well as confirm and organize information. Thus, learners will be creative in different dimensions and cooperate with each other to solve problems. Therefore, at the end of each teaching activity, the researcher asked the students to fill in a learning sheet on a weblog (see Fig. 3) and then analyzed these learning sheets to recognize the students' learning, attitude, progress, obstacles and questions. The process not only diagnosed the feasibility of instructional activities and the design of future activities, but also functioned as a criterion for evaluating students' learning outcomes.

After the end of each unit course, students were interviewed randomly, allowing for students to freely share personal opinions. The researcher would then evaluate their learning situations by carrying out informal interviews and analyzing the data to obtain more information in order to modify action research. The teachers' teaching journal includes three stages: (1) prior to implementation of instructional activity: related to the teachers' recognition of "practical monograph" and its importance and their thoughts of and approaches towards the instruction; (2) during implementation of instructional activity: refers to the obstacles, review of problems, responses and modification during

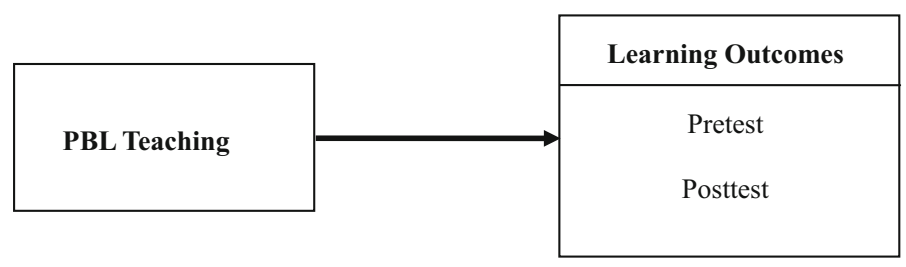

Fig. 2 Research framework of questionnaire survey 


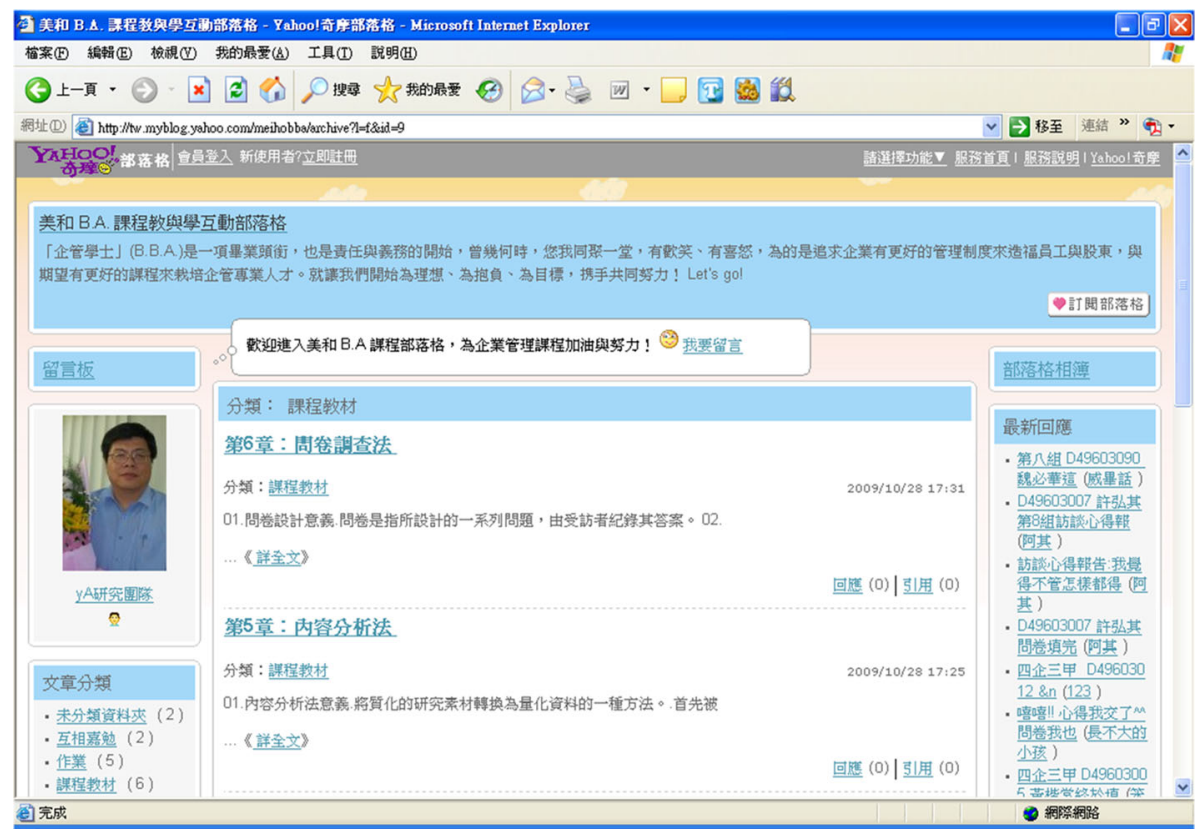

Fig. 3 Learning sheet on the weblog

implementation of three units (generic competence, professional competence and workforce competence); (3) after implementation of instructional activity: according to students' learning outcomes, collaborative teachers' suggestions and feedback, the researcher reviews, allowing consideration and modification of the process of instruction and proposes specific measures for future instruction or studies.

Each instruction period was individually recorded by video camera. After instruction, the recording was transcribed and the researcher who reviewed the reactions of teachers and students and used them as the criteria for the next instruction. The "Questionnaire survey" was based on a one-group pretest and posttest of quasi-experimental design, with the "scale of graduates' industrial orientation of the business department of technological and vocational institutes" from Yeh et al. (2010). The Pretest was conducted in the first week (before PBL) and the posttest was conducted in the 11th week (after PBL). There were 51 questionnaires collected with $100 \%$ return and availability rates.

\section{Data coding}

The qualitative data collected were reorganized and encoded. Data coding are as follows: $\mathrm{T}$ is record for instructional activity, $\mathrm{C}$ is for classroom observation record, $\mathrm{L}$ for learning sheet, I for interview record, R for teachers' journals, TR for teaching video recording; codes of characters: $\mathrm{T}$ is the instructor (researcher) and $\mathrm{S}$ is student; codes of group: from 1 to 15 ; codes of members: from 1 to 5 ; there are dates of each data. In order to protect students' rights and privacy, the researcher encoded each student with a number for data collection and analysis. For instance, I-S-1-2-20091126 represents the interview record, student, the first group, the second member and date. The full translation would therefore 
be "interview record of the second student in the first group on November 26, 2009". Data collected after the questionnaire survey was then encoded into the serial numbers and decoded according to students' numbers and then stored into the computer.

\section{Data analysis}

After coding of qualitative data, the researcher reorganized the contents that are relative to industrial-oriented competences, reviewed the primary data, generalized and analyzed it to find the same or similar incidents, content view and development and reflection of instruction. Important concepts were analyzed to select the more representative and critical sentences and paragraphs. Quantitative data was analyzed by SPSS 14.0 for Windows, descriptive statistics, paired sample $t$ test, product-moment correlation and independent sample $t$ test.

\section{Reliability and validity test}

Since this study was based on the qualitative approach and the record referred to observation and interview, an inter-observer agreement test was required. In order to avoid subjectivity, the researcher and the other two teachers were the observers. According to the formula below, reliability of "inter-observer consistency" was conducted so that the reliability percentage must be at least $80 \%$ (Cohen 1960; Brennan and Prediger 1981; Tawney and Gast 1984). Three reliability tests were conducted with these results: $85.5,87$ and 87.5. Average outcome is $86.6 \%$ which was acceptable:

$$
\begin{gathered}
\mathrm{X}=\text { frequency of } \mathrm{AB} \text { observers' consistent record } \\
\mathrm{Y}=\text { frequency of } \mathrm{AB} \text { observers' inconsistent record } \\
\text { Reliability of inter-observer consistency }=[\mathrm{X} /(\mathrm{X}+\mathrm{Y})] \times 100
\end{gathered}
$$

Concerning the objectivity of the qualitative study, the system and quantitative description, the researcher invited two teachers from the business administration department of a technological university to review and modify the internal and external validity. This study also used the "scale of graduates' industrial orientation of the business department of technological and vocational institutes" of Yeh et al. (2010) as a tool of quantitative study. The statistical analysis result showed that mean (M) and mode (Mo) of each core competence were above four and Cronbach $\alpha$ of internal reliability is .935 . This showed the consistency of the core competences was high. Absolute values $(|\mathrm{Mo}-\mathrm{M}|)$ of differences between modes and means of core competences were below 1. Mean of all $|\mathrm{Mo}-\mathrm{M}|$ was 0.27 . This means that the scale reveals good expert validity (Osborne et al. 2003; Wen and Shih 2008).

\section{Data analysis and results}

This study conducted instructional activities that covered three teaching subjects and lasted for 11 weeks. The main purpose was placed on examining the influences of PBL in practical monograph classes on the industrial-oriented competences at technological universities. After participating and observing in the classrooms, as well as reviewing teachers' instructional journals and semi-structural interviews, the results indicated the 
following: (1) Practical monograph is originally intended as a lecture-type course. After applying PBL, the instructional activity became more interesting and enhanced the students' learning outcomes; (2) The questionnaire surveys were conducted by using the SGIOC questionnaire to investigate students' industrial-oriented generic competence, professional competence and workforce competence. Students would thus then recognize their current industrial-oriented competences and competence-items that needed to be further enhanced. This should significantly enhance and equip their competences in future workplaces after graduation. As suggested by the Chinese saying, "knowing the enemy as well as yourself will get you through a hundred battles unscathed without defeat;" (3) Generally speaking, this study was based on PBL and encouraged students to learn actively. It combined instructional activities with their daily lives. Students searched for information they needed and they thought about and solved their problems according to the circumstances. Both observations in the classroom and interview records have demonstrated positive outcomes. Although PBL teachers must spend more time during instructional activity, they were pleased when recognizing students' attentive learning and growth of learning outcomes according to teachers' teaching journals.

\section{Analyses of classroom observation and interview record for student's activities}

For the three teaching subjects conducted in the 11 weeks span, the researcher's observed that after being involved with PBL, students became more concentrated in learning course content. Applying PBL teaching strategy as proposed by Delisle (1997) and Hong (2001), students started to proactively learn the course subjects, analyze problems, share their thoughts and feelings and were more willing to pose questions and express their own ideas, opinions and perspectives for discussion. Teacher's instructional activity could attract student's attention because of the new teaching approach. Students gradually became more involved in the instruction and feel the learning was easy and fun. These results agreed with the research findings of Aleman and Lopez (2000), Finkle and Trop (1995), HaithCooper (2000), Jih and Chang (2001), Schank (1994), Song et al. (2006). The following are some interview records illustrated by the students:

S07: I am an introvert. I thought it was a traditional teaching-type course in a classroom. Instructional activity was designed by the teachers to draw my attention. Every time I encountered questions, I raised my hand and asked the teacher. By guidance, the teacher helped me to find the answer. I was really happy because I was finally able to open up and ask questions!

S29: I have studied at the university for three years and it was the first time that I was not afraid of answering the questions in front of the teacher and classmates in class. In other words, I could freely share my opinions and thoughts.

S36: Classmates raised their hands rapidly at "who is first" question time. It reminded me of the time in kindergarten. When the teacher lectured, everyone listened quietly. However, when the teacher asked "Any questions?" everyone would try to be the first.

S04: The seniors told me that we will try to produce a graduation project in the "practical monograph" course. I skipped the first class but my classmates told me the class was fun and the teacher was humorous. I was curious and took the second class. I realized that what they had said was true! 
S47: I am an "owl” (awake all night) and I am used to falling asleep in class. After taking this course, I have changed my daily routine as the teaching method and content were awesome. I had to totally concentrate in class.

In the "practical monograph" course, the PBL approach allows the students to internalize their learning and enhance their learning outcomes. Students realized their advantages and disadvantages and could enhance the competences needed before graduation. A few students applied what they learned through PBL into their part-time job or home business and found positive outcomes. Students became self-oriented learners, they learned for the sake of learning and gradually constructed their own industrial-oriented competences, including generic competence, professional competence and workforce competence. PBL can therefore enhance students' learning motivation and their learning outcomes to adapt to reality in the future workplace. The result agrees with the research findings of Wu (2002), Margetson (1991), Engel (1997) and Hallinger and Bridges (2010). The followings are some interview records of students:

S41: The teaching method of "practical monograph" was new to me and I did not feel bored in class.

S25: Wow! I was interested in the research approaches and how to manage them! Finally I learned "case study." From data collection, interview with employers and employees, content analysis, and induction of key points, I have learned the knowledge, skills and attitudes which I could not absorb from textbooks.

S14: I thought we only had to use the computer. After taking this course, I realized that we could analyze data collected by statistical software.

S09: "Finance and Accounting" is my weakest subject. In this course, I finally realized that they are always in our daily lives, such as stocks, risk planning, accounting, and financial statement analysis. I was not afraid of them anymore.

S19: I thought "E-commerce" meant selling things online. However, after the teacher explained the website, "amazon.com," I realized the content and application scope of E-commerce.

S38: In learning, I applied "marketing planning" competence to my home business and the sales increased. Now I have taught my father what I have learned in class and increased his sales volume.

S40: Currently, society lacks "ethics," particularly "work ethic" in the workplace. I enjoyed the teacher's training about our responsibility and loyalty to work.

S31: Finally, I learned how to have an "expert interview" and "questionnaire survey." I was really glad since my graduation project was on the analysis of business and management of hyper-markets which was a qualitative study as the main method and quantitative study as the secondary approach.

As we can see from the above interview records, after experiencing the PBL, the majority of business and management students thought that they enjoyed the PBL process in the practical monograph course. Through the interpersonal interaction with team members and the instructor in group discussion, they could practically realize the importance of "how to solve problems," particularly in the logic of analyzing problems and learning the practical competences regarding how to train themselves step by step. Some of the students also indicated that the novel and effective teaching approach of PBL could help them more confidently share their ideas, thoughts experiences and lessons learned in physical classroom and on virtual learning weblog. Through the problems given by, and guidance at levels appropriate to their comprehension from the teacher, they were inspired 
to proactively practice collecting, sorting, and analyzing evidence and in building arguments based on careful observation and thoughtful analysis. They became involved in the course and gradually received collective course instruction and learned "how to learn" by themselves.

Moreover, the students also found that the PBL learning approach was easy and fun and could well gratify their learning needs for industrial-oriented competences. Some of the students who served as the team leaders also signified that they were responsible for arranging the works according to classmates' talents in order to fulfill the assignments in the shortest time, fulfill their talent in leadership, and guide the members to solve the problems. They all recognized that the advantages of PBL in the classroom could help them cultivate their competences in teamwork. After the test of industrial-oriented competences, they could not only learn professional competences, but also realized that their workforce competence was inferior to their generic competence through the practical monograph course with PBL teaching. All students thought that the practical monograph could really help them to review their levels of industrial-oriented competences and help them comprehensively recognize their strengths and weakness and enhance the competences needed before graduation. In essence, the application of PBL in the course could enhance students' learning by providing a highly motivational environment for acquisition of knowledge. Management-major students in particular could cultivate the competence before entering the workplace. The advantage of PBL is in preparing college students in business and management to practically understand the challenges of contemporary business world. The above results imply that the emphasis of PBL curricula on application of domain knowledge, problem solving, higher order thinking, and self-directed learning skills can equip students with professional and life-long learning habits, which are indispensable qualities of successful business management professionals.

\section{Teachers' teaching journals and analysis of interview record}

Although PBL is widely applied to medical education, it is rarely used in management education (Boud and Feletti 1998; Wilkerson and Gijselaers 1996). PBL is an instrumental teaching strategy which guides students to solve problems. The process is effective in cultivating the learners' critical thinking and problem solving competences. However, after action research, this study proposes using PBL to design teaching plans. After the experiment, the researcher realized that teachers must implement their instruction according to a teaching plan in order to allow the students to be challenged by the problems and search for solutions. Students can explore new knowledge from experience and further acquire more practical experience to become better self-learners with competence. Teachers record every detail of instructional activity and discover problems by self-reflection and can modify their action strategy to solve the problems encountered in teaching. The result agrees with the findings of Hewitt-Taylor (2002), Connolly and Donovan (2002). The followings are some interview records from the teachers:

For me, this was an in-classroom course. At the beginning, PBL instruction was a burden. However, after the formal instruction, I was deeply touched by students' smiles, sharing of opinions, group discussion, determination to solve problems, and presentation on the stage. We could enhance students' learning motivation by simply changing the teaching method.

I was more impressed by the question time response in "who wants to be first." The students who were originally not active to express themselves now try to be the first 
to answer the questions. The classroom atmosphere had therefore changed. It was a rare situation in my experience.

"Appropriate prizes and immediate rewards" are helpful for enhancing students' learning motivation and learning outcomes. These rewards are particularly effective when students feel depressed or encounter learning difficulties.

By formative evaluation, diagnostic evaluation and summative evaluation, students' learning outcomes are learned and each student's learning situation is controlled to guide the students or adjust course content and teaching method as the criteria for the next teaching activity.

PBL was already known to be effective in medical education. This was the first time I applied it to instruction and management education. After going through PBL for 11 weeks, the students made progress in learning motivation or learning outcomes. I strongly believe that PBL is an effective teaching approach in management education.

According to the studies of Barrett (2005), Sage (2000) and Stepien (2002), a combination of PBL and information technology tools will favorably and more effectively select, confirm and organize information, thus allowing learners to solve problems together with multiple approaches.

In the practical monograph course, by using the "weblog learning sheet," we initially allowed students to answer the questions online in the regulated time and from anyplace. For teachers, it can enhance students' high level cognitive and thinking competences.

Students were interested in weblog instruction. It drew their attention to the class and enhanced their learning motivation. Teachers' instruction was further enhanced. It is also a kind of stimulation for teachers to continue the job.

Thus, in online instruction, teachers must recognize the characteristics of the internet and design a problem-solving centered and student-based online collaborative learning strategy. Thus, teachers and students will share the learning pleasure, cultivate problem-solving competence and adapt to social change.

In fact, with PBL, most of the students in class can actively acquire information through the library, computer data and online resources. They can have independent learning and collaborative learning regarding their learning issue. It can effectively reduce the frequency of teachers' individual instruction. It is the first effective learning approach which I have come across since being a teacher.

Regarding the learning outcomes of industrial-oriented competences, this study found that after comparing students' outcomes in pre and post-learning, the researcher realized that PBL can substantially enhance learning outcomes in management education. The results agree with the research finding of Hallinger and Bridges (2010). PBL is an educational model which compensates for the disadvantages of traditional instruction and results in more meaningful and effective learning outcomes of students. It helps the students to learn how to learn.

In order to meet students' prior knowledge when we planned the instructional activity, a pretest was implemented in the first week by using a SGIOC questionnaire. 
Based on the students' past learning process and interview with their teachers, we recognized students' learning behavior to further design a teaching plan and instruct students' knowledge and skill.

In the 11th week of teaching, a posttest was conducted to compare the influences on industrial-oriented competences before and after learning. Although the instructional activity was tough, it was enjoyable to see students' progress in learning outcomes. The students in this class were juniors and they were preparing for their graduation project reports with 3-5 members in a team. They needed to demonstrate their knowledge and skills learned in university in the report.

Economic development in Taiwan relies on the prevalence of education which rapidly expands educational outcomes. In Taiwan, the university entrance rate has increased to $98 \%$ since 2008 . We can no longer teach the students in the internet era with old methods so we must include information technology in instruction and adopt an effective teaching approach to enhance the students' learning motives and learning outcomes.

After PBL teaching in the practical monograph course, the teachers showed that PBL could serve as an instrumental teaching strategy which guides students to solve problems. In the process of PBL teaching, they found that the students obtained key knowledge, skills and competences (such as data collection analysis and presentation, critical thinking, interpersonal cooperation and problem solving) by cooperating with others to collect information, share opinions, and select problem solving plans. In a broad sense, PBL is an educational model which reflects the reality of the workplace and daily life. It could act as the framework of the curriculum and guide for the teachers in designing courses, helping students learn how to learn. The objective is to cultivate the competence instead of simply obtaining the knowledge. In a traditional instructional environment, there are always disadvantages regarding the limit of teaching hours and curriculum structure. The teaching and learning modes in such teacher-centered circumstance tend to emphasize memorizing the teaching's contents and simply passing the knowledge to students who passively accept it. It cannot cultivate students' critical thinking and problem solving competences. In contrast, PBL can not only provide students with academic knowledge, but also can allow students to ponder on the best solutions. The practical monograph course with the implementation of PBL provided before the students' graduation facilitates students probing into industrial practices and to discover social problems in order to solve them. PBL is a student-based learning process. By recognizing the connection between knowledge and reality and having interest and competence in active learning, it compensates for the disadvantages of traditional instruction and results in more meaningful and effective learning outcomes for students. The PBL approach is related to issues in reality and there are no standard answers to questions posed by PBL so learners must constantly think, study the problems and develop solutions to solve them. The teachers who applied the PBL process in the practical monograph course indicated that it was indeed effective in cultivating the learners' critical thinking and problem solving competences.

\section{Quantitative analyses}

As to the quantitative study, the questionnaire survey was conducted by applying the "industrial-oriented competences scale" developed by Yeh et al. (2010) in a pretest before PBL and a posttest after PBL. Statistical analysis was conducted by descriptive statistics, 
Table 2 Profile of the participants

\begin{tabular}{llcc}
\hline Background variables & Group & Number of people & Percentage (\%) \\
\hline \multirow{2}{*}{ Gender } & Male & 27 & 52.9 \\
& Female & 24 & 47.1 \\
Daily studying time & None & 9 & 17.6 \\
& Within 1 h & 28 & 54.9 \\
& 1-2 h & 11 & 21.6 \\
Planning after graduation & Above 2 h & 3 & 5.9 \\
& Advanced study & 7 & 13.7 \\
& Employment & 34 & 66.7 \\
& Military service & 10 & 19.6 \\
\hline
\end{tabular}

Table 3 Paired sample $t$ test

\begin{tabular}{|c|c|c|c|c|c|c|c|c|}
\hline \multirow[t]{2}{*}{ Variables } & \multicolumn{2}{|c|}{$\begin{array}{l}\text { Pre-test } \\
(n=51)\end{array}$} & \multicolumn{2}{|c|}{$\begin{array}{l}\text { Post-test } \\
(n=51)\end{array}$} & \multirow[t]{2}{*}{$t$ value } & \multirow[t]{2}{*}{$p$ value } & \multicolumn{2}{|c|}{$95 \% \mathrm{CI}$} \\
\hline & Mean & SD & Mean & SD & & & LL & UL \\
\hline Generic competence & 12.41 & 2.34 & 14.22 & 1.94 & -4.18 & $p<.001$ & -2.67 & -0.94 \\
\hline Professional competence & 20.80 & 3.99 & 23.55 & 3.85 & -3.56 & $p<.01$ & -4.30 & -1.19 \\
\hline Workforce competence & 18.16 & 3.11 & 19.78 & 3.75 & -2.24 & $p<.05$ & -3.09 & -0.17 \\
\hline $\begin{array}{l}\text { Total scale of industrial-oriented } \\
\text { competences }\end{array}$ & 51.37 & 7.83 & 57.55 & 8.33 & -3.91 & $p<.001$ & -9.35 & -3.00 \\
\hline
\end{tabular}

$d f=50$

paired sample $t$ test. Table 2 showed the profile of 51 students who participated the class. The number of males and females were similar. Regarding "daily studying time," there were 48 students who spent less than 2 hours daily in studying. Some of them worked parttime after school hours due to their family financial condition. This means that with a busy studying life, students still arranged time to review their work. As to "plans after graduation," rather than studying for an advanced degree, most of the students have chosen to work full-time, except for the time required for national mandatory military service applied to all for male students. Most students treat jobs as their first priority and they plan to apply their competences to the industrial world after graduation.

Table 3 showed the paired sample $t$ test of pre-test and post-test of 51 students for each competence category. "Generic competence," "Professional competence," and "Workforce competence" all revealed significant difference between pre-test and post-test. All mean values of post-test were significantly higher than the mean values of pre-test. Overall, the "industrial-oriented competences" also revealed significant differences between pretest and post-test. In summary, PBL can actually enhance industrial-oriented competences of business and management-majored students.

As the results in Table 4 showed, the categories of male and female do not reveal significant difference in scores of sub-scales "generic competence," "professional competence," "workforce competence," and total scale of "industrial-oriented competences." 
Table 4 Independent sample $t$ test of different gender

\begin{tabular}{|c|c|c|c|c|c|}
\hline \multirow[t]{2}{*}{ Variables } & \multicolumn{2}{|c|}{ Male $(n=27)$} & \multicolumn{2}{|c|}{ Female $(n=24)$} & \multirow[t]{2}{*}{$\operatorname{Sig}(2$-tailed) $t$ test } \\
\hline & Mean & SD & Mean & SD & \\
\hline Total scale of industrial-oriented competences & 56.78 & 8.74 & 58.42 & 7.94 & -0.70 \\
\hline \multicolumn{6}{|l|}{ Sub-scale of generic competence } \\
\hline Generic competence & 14.15 & 2.05 & 14.29 & 1.85 & -0.26 \\
\hline 1. Using computers & 3.89 & 0.70 & 3.79 & 0.78 & 0.47 \\
\hline 2. Communication & 3.56 & 0.70 & 3.88 & 0.74 & -1.58 \\
\hline 3. Language skills & 3.15 & 0.77 & 3.17 & 0.70 & -0.09 \\
\hline 4. Problem-analysis and problem-solving & 3.56 & 0.70 & 3.46 & 0.51 & 0.56 \\
\hline \multicolumn{6}{|l|}{ Sub-scale of professional competence } \\
\hline Professional competence & 23.30 & 4.06 & 23.83 & 3.66 & -0.49 \\
\hline 1. Production and operation management & 3.44 & 0.64 & 3.50 & 0.72 & -0.29 \\
\hline 2. Marketing management & 3.37 & 0.63 & 3.38 & 0.82 & -0.02 \\
\hline 3. Customers relationship management & 3.59 & 0.75 & 3.63 & 0.82 & -0.15 \\
\hline 4. Human resources management & 3.56 & 0.64 & 3.79 & 0.78 & -1.19 \\
\hline 5. Financial management & 3.26 & 0.94 & 3.04 & 0.62 & 0.98 \\
\hline 6. Accounting and statistical analysis & 2.93 & 0.87 & 3.04 & 0.69 & -0.52 \\
\hline 7. E-commerce applications & 3.15 & 0.99 & 3.46 & 1.02 & -1.10 \\
\hline \multicolumn{6}{|l|}{ Sub-scale of workforce competence } \\
\hline Workforce competence & 19.33 & 3.97 & 20.29 & 3.51 & -0.91 \\
\hline 1. Team work & 4.07 & 0.78 & 4.38 & 0.77 & -1.38 \\
\hline 2. Self-learning & 3.85 & 0.95 & 3.92 & 0.83 & -0.26 \\
\hline 3. Self-discipline & 4.07 & 0.78 & 4.04 & 0.69 & 0.16 \\
\hline 4. Leadership & 3.48 & 0.98 & 3.79 & 0.88 & -1.18 \\
\hline 5. Work ethic & 3.85 & 0.99 & 4.17 & 1.01 & -1.13 \\
\hline
\end{tabular}

PBL teaching was conducted on heterogeneity student groups. Students contributed their knowledge and experience through cooperative learning processes. Therefore, males' and females' industrial-oriented competences were not different due to gender after PBL.

\section{Conclusions}

This study applied PBL to a practical monograph course of business management education in technological and vocational institutes. Both qualitative study and quantitative study were conducted. By applying PBL in the practical monograph course, the researcher investigated the influence on students' industrial-oriented competences. According to the observation in the classroom and interview with students and the teachers, after the implementation of PBL, the instructional activities became more interesting to students. The learning method changed from static to dynamic. The learning weblog, in particular, not only drew students' attention and increased their learning interests, but also allowed students to review their work on line at home. The forum can enhance the interaction between 
teachers and students, and between students. All of the students in the practical monograph course indicated that they were satisfied with PBL.

By applying PBL in a practical monograph course, teachers may feel there is an extra workload to prepare for, such as teaching plans, observations in classroom, interviews and journals of reflection. However, after being made familiar by experience with the whole process of PBL, teachers were able to enjoy it and were satisfied with students' learning motivation and increased learning outcomes. It significantly enhanced the development of instructional knowledge and capability. After PBL, students' industrial-oriented competences revealed significant differences in pre-test and post-test. It showed that PBL is a preferred teaching approach to train the learners' high level of thinking competence. The instructors played the role of promoters or instructors, and learners gradually constructed knowledge by team work and self-learning. Students make significant progress in learning outcomes by being stimulated with realistic questions. It demonstrated the results of Hallinger and Bridges (2010) that PBL can be applied to management education and improved student's learning outcomes. This study adopted the "scale of graduates' industrial orientation competences in the business management department of technological and vocational institutes" of Yeh et al. (2010) as a tool of quantitative study. The result shows that it can measure industrial-oriented competences of business and managementmajored students in technological universities. Teachers can implement individual guidance or adjust course content and teaching approach according to students' competences. Thus, students can be equipped with industrial-oriented competence needed by the workplace before graduation.

Following the above analysis, some suggestions for future research are: First, teachers of management education should follow the implementation strategy of PBL applied in this study. By using the industrial-oriented competences scale, they will be able to recognize students' learning needs and outcomes regarding generic, professional, and workforce competences for the cultivation of industrial-oriented core competences. Thus, students could learn industrial-oriented competences through practical courses in business and management colleges and be prepared for employment after graduation. Second, the administration departments of schools should investigate the graduating management students by this scale to allow the students to find whether their competences learned in the 4 years of college meet the demand in the industrial world. Finally, for the objectivity of "industrial-oriented competences scale," future researchers should investigate management students in greater scope in order to construct a normal model as criterion for educational units. They can extend competence measurements based on the 16 core competences developed by Yeh et al. (2010).

Understanding the importance of critical industrial-oriented competences for businessmajor college students is crucial in successful core competence development for modern firms. Thus, this study investigated the influences of PBL in practical monograph classes on the industrial-oriented competences at technological universities. The research findings can shed light on the teaching and learning strategy of college students' industrial-oriented competences. Explicitly, after participating in and observing the classrooms, as well as reviewing teachers' instructional journals and semi-structural interviews, the results of this current study can be concluded as the following: (1) Though practical monograph was originally intended as a lecture-type course, after applying PBL to practical monograph, the instructional activity became more interesting and enhanced the students' learning outcomes; (2) By using the SGIOC questionnaire, the questionnaire survey conducted to investigate students' industrial-oriented generic, professional and workforce competences, students would then recognize their current industrial-oriented competences and 
competence-items that needed to be further enhanced. This significantly enhanced and equipped their competences in future workplaces after graduation. (3) By applying the PBL approach in the practical monograph course, the teaching and learning strategy was proven to actually encourage students to learn proactively, and cultivate them with critical thinking and problem solving knowledge, skills and attitudes to accumulate industrialoriented competences for their future career. Students searched for information they needed and solved their problems according to the ever-changing circumstance. Both observations in classroom and interview records have demonstrated positive outcomes. The empirical results can serve as practical guidelines for the related practical monograph courses of business and management education to be effectively designed and implemented with care to avoid the risk to attenuate business college students' interests as well as increase their proficiency of industrial-oriented core competences. The researchers in this study expect the findings to contribute to the theoretical implications and for the future of educational and industrial development to help avoid current discrepancies and close the gap between vocational education and the practical demands of industries.

Acknowledgments The authors greatly appreciate the financial support provided by the National Science Council, Taiwan, ROC, under contract No. NSC 97-2511-S-276-001-MY3, and also the kind assistance of Dr. Sheng-Huang Kuo, Ms. Yung-Chieh Jen and Ms. Shih-Jung Chen, who made this article possible.

Open Access This article is distributed under the terms of the Creative Commons Attribution 4.0 International License (http://creativecommons.org/licenses/by/4.0/), which permits unrestricted use, distribution, and reproduction in any medium, provided you give appropriate credit to the original author(s) and the source, provide a link to the Creative Commons license, and indicate if changes were made.

\section{References}

Aleman, E. C., and Lopez, C. A. N. (2000). Problem-based learning in materials and manufacturing engineering education. In Proceedings of inter tech 2000, 14-17 June. USA, Ohio.

Barrett, T. (2005). What is problem-based learning? In G. O'Neill, S. Moore, \& B. McMullin (Eds.), Emerging issues in the practice of university learning and teaching (pp. 55-66). Dublin: All Ireland Society for Higher Education (AISHE).

Boddy, D., Paton, R., \& MacDonald, S. (1995). Competence-based management awards in higher education? Management Learning, 26(2), 179-192.

Boud, D., \& Feletti, G. I. (1998). The challenge problem-based learning. London: Kogan Page.

Brennan, R. L., \& Prediger, D. J. (1981). Coefficient kappa: Some uses, misuses, and alternatives. Educational and Psychological Measurement, 41(3), 687-699.

Burchell, N., Hodges, D., \& Rainsbury, L. (1999). What competencies does the workplace expect for business graduates? Some perspectives of the top 500 companies in New Zealand. In D. Hodges \& C. Eames (Eds.), Proceedings of the third annual conference of the New Zealand association for cooperative education (pp. 1-12). Rotorua, New Zealand: New Zealand Association for Cooperative Education.

Burchell, N., Hodges, D., \& Rainsbury, L. (2000). What competencies do business graduates require? Perspectives of New Zealand stakeholders. Journal of Cooperative Education, 35(2-3), 11-20.

Calway, B. A., \& Murphy, G. A. (2000). Career progression of cooperative education graduates. Journal of Cooperative Education, 33(2-3), 68-75.

Chen, W. L. (2010). Project research: Concepts, methods and cases. Taipei: Chuan Hwa Book Publishing. (in Chinese).

Cohen, J. (1960). A coefficient of agreement for nominal scale. Educational and Psychological Measurement, 20, 37-46.

Connolly, D., \& Donovan, M. (2002). Introducing a problem-based learning module into an occupational therapy course. Learning in Health and Social Care, 1(3), 150-157.

Delisle, R. (1997). How to use problem-based learning in the classroom. VA: Association for Supervision and Curriculum Development. 
Dick, B. (2002). Action research: Action and research. Action learning and action research, URL (consulted Jan 2011) http://www.scu.edu.au/schools/gcm/ar/arp/aandr.html.

Elliott, J. (1991). Action research for educational change. London: Open University Press.

Engel, C. E. (1997). Not just a method but a way of learning. In D. Boud \& G. E. Feletti (Eds.), The challenge of problem-based learning (pp. 17-27). London: Kogan Page Limited.

Felder, R. M., \& Brent, R. (2005). Understanding student differences. Journal of Engineering Education, 94(1), 57-72.

Finkle, S. L., \& Torp, L. L. (1995). Introductory documents. USA: The Center for PBL, Illinois Math and Science Academy.

Gordon, G. G. (1991). Industry determinants of organization culture. Academy of Management Review, $16(2), 396-415$.

Haith-Cooper, M. (2000). Problem-based learning within health professional education. What is the role of the lecturer? A review of the literature. Nurse Education Today, 20, 267-272.

Hallinger, P., \& Bridges, E. M. (2010). A problem-based approach for management education: preparing managers for action. Dordrecht: Springer.

Hewitt-Taylor, J. (2002). Teachers' and students' views on self-directed learning. Nursing Standard, 17(1), 33-38.

Hong, J. C. (2001). PBL teaching strategy. Technological and Vocational Education Bimonthly, 61, 10-12.

Hung, W. T. (2008). Study on the commercial technology development of industry-oriented courses. National science council research project. Taipei: National Science Council. (in Chinese).

Hung, W., Jonassen, D. H., \& Liu, R. (2008). Problem-based learning. Handbook of Research on Educational Communications and Technology, 3, 485-506.

Jih, H. J., \& Chang, H. F. (2001). The instructional design model for problem-based learning. Instructional Technology and Media, 55, 58-71.

Jou, I. C. (2009). Construction industry based learning into pragmatic multiple talents. URL (consulted January 2011) http://www.sec.nkfust.edu.tw/enews/980715-2.pdf (in Chinese).

Keegan, A., \& Turner, J. R. (2001). Quantity versus quality in project-based learning practices. Management Learning, 32(1), 77-98.

Lysaght, R. M., \& Altschuld, J. W. (2000). Beyond initial certification: The assessment and maintenance of competency in profession. Evaluation and Program Planning, 23, 95-104.

Mager, R. (1962). Preparing objectives for programmed instruction. San Francisco: Fearon Publishers.

Management Charter Initiative. (1990). Crediting competence. London: MCI.

Margetson, D. (1991). Why is problem-based learning a challenge. In D. Boud \& G. Feletti (Eds.), The challenge of problem-based learning (pp. 36-44). London: Kogan Page.

McClelland, D. C. (1973). Testing for competence rather than for intelligence. American Psychologist, 28, $1-14$.

McNiff, J. (1988). Action research: Principles and practice. New York: Macmillan.

NSC (National Science Council). (2008). Industrial-oriented quality of higher technical education. Department of Science Education, URL (consulted January 2011): http://www.nsc.gov.tw/sci/ct. asp? XItem $=13884$ andctNode $=1618$.

Osborne, J., Colins, S., Ratcliffe, M., Millar, R., \& Duschl, R. (2003). "What Ideas-about-Science" should be taught in school science? A Delphi study of the expert community. Journal of Research in Science Teaching, 40(7), 692-720.

Ou, Y. S. (1999). Action research and innovation in school education. Elementary education, 39(5), 2-12. (in Chinese).

Pittaway, L., \& Cope, J. (2007). Simulating entrepreneurial learning: integrating experiential and collaborative: Approaches to learning. Management Learning, 38(2), 211-233.

Reason, P., \& Bradbury, H. (2001). Handbook of action research: Participative inquiry and practice. London: Sage.

Roberts, R. W. (1957). Vocational and practical arts education. New York: Harper \& Brothers.

Sadler-Smith, E., Hampson, Y., Chaston, I., \& Badger, B. (2003). Managerial behavior, entrepreneurial style, and small firm performanc. Journal of Small Business Management, 41(1), 47-67.

Sage, S. (2000). A natural fit: Problem-based learning and technology standards. Learning and Leading with Technology, 28(1), 6-12.

Schank, R. (1994). Engines for educators. NJ: Lawrence Erlbaum Associates.

Song, H.-D., Grabowski, B., Koszalka, T. A., \& Harkness, W. L. (2006). Patterns of instructional-design factors prompting reflective thinking in middle-school and college level problem-based learning environments. Instructional Science, 34, 63-87.

Stepien, W. J. (2002). Problem-based learning with the internet, Grades 3-6. Arizona: Zephyr Press.

Tawney, J. W., \& Gast, D. L. (1984). Single subject research in special education. OH: Charles E. Merrill. 
Thorpe, R., \& Holman, D. (1994). The management charter initiative in higher education: An evaluation of its applicability to undergraduate. Conference Report in HEC's Academic Journal Capability, 1(1), 43-52.

Tseng, K. H., Chiang, F. K., \& Hsu, W. H. (2008). Interactive processes and learning attitudes in a webbased problem-based learning (PBL) platform. Computers in Human Behavior, 24(3), 940-955.

Weinert, F. E. (1999). Concepts of competence. Munchen: Max Planck Institute.

Wen, J. R., \& Shih, W. L. (2008). Exploring the information literacy competence standards for elementary and high school teachers. Computers \& Education, 50(3), 787-806.

West, D. J. and Watson, D. E. (1996). Using problem-based learning educational reengineering to improve outcomes. ERIC Document Reproduction Service No. ED 400242.

Wilkerson, L., \& Gijselaers, W. H. (1996). Concluding comments. New Directions for Teaching and Learning, 68, 101-104.

Wu, C. S. (2002). Problem-based learning. Journal of Education Research, 97, 120.

Yeh, R. C., Chen, Y. C., \& Kuo, S. H. (2010). Industry-oriented competency requirements of business administration-majored technological university students in Taiwan. World Transactions on Engineering and Technology Education, 8(4), 431-435. 